\title{
CAMPAIGN FOR INSPECTION AND EXCHANGE OF PARTY DOCUMENTS AS A REFLECTION OF POLITICAL TECHNOLOGIES OF STALIN'S REGIME IN THE UPPER VOLGA REGION IN 1935-1936
}

\author{
Kirill A. Yudin \\ Ivanovo State University, Ivanovo, Russian Federation
}

\begin{abstract}
This article is devoted to one of the most important administrative and political actions initiated by Stalin's regime in the mid-1930s - campaigns on verification and exchange of party documents. The author made an attempt to examine the whole course of the campaign as much as possible in detail, from the preparation stage at the beginning of 1935 until its completion in the autumn of 1936 in a particular historical and geographical location - in the areas of the Upper Volga region. Documentary base of this research were, first of all, archival materials, introduced into scientific circulation for the first time.

In this article series on the basis of the evidence the author reveals the following provisions. Firstly, investigation of party documents represented a large-scale ideological and political examination covering all regions - intra-party filtering of communists for "political reliability". Secondly, the immediate aim of the campaign was to collect materials compromising the Communists and to make a list of the potentially repressed. One of the most important tools for carrying out the "ideological examination" of the Party and Soviet nomenclature used together with public security bodies in the territory of the Upper Volga region in the mid-1930s, was represented by the Party Control Commission (CPC) at the Central Committee of the CPSU (b) and its regional structure - Communist Party Collegium and later by the authorized representatives of the CPC of the Ivanovo and Yaroslavl regions.

The author makes the general conclusion - campaign for the exchange and verification of party documents became the representative illustration of methodologically verified political technologies of the Stalin's regime, as evidenced by its course: organization; full control by the center by means of directives; efficiency manifested in revealing "socially alien elements" recorded statistically for CPC line.
\end{abstract}

Key words: party-political control, methods and technologies of power, social filtering, party nomenclature, Stalin's regime, Upper Volga region, repressions.

\section{КАМПАНИЯ ПО ПРОВЕРКЕ И ОБМЕНУ ПАРТИЙНЫХ ДОКУМЕНТОВ КАК ОТРАЖЕНИЕ ПОЛИТИЧЕСКИХ ТЕХНОЛОГИЙ СТАЛИНСКОГО РЕЖИМА НА ТЕРРИТОРИИ ВЕРХНЕВОЛЖСКОГО РЕГИОНА В 1935-1936 ГОДАХ}

\author{
Кирилл Александрович Юдин \\ Ивановский государственный университет, г. Иваново, Российская Федерация
}


На основе фактических данных в статье последовательно раскрываются следующие положения. Вопервых, проверка партдокументов представляла собой масштабную, охватывающую все регионы, идейнополитическую аттестацию - внутрипартийную фильтрацию коммунистов на предмет «политической благонадежности». Во-вторых, непосредственной целью кампании был сбор компрометирующих материалов на коммунистов и составление «картотеки» потенциально репрессированных. Далее, одним из ведущих инструментов, осуществлявших вместе с органами государственной безопасности «идеологическую экспертизу» партийно-советской номенклатуры на территории Верхневолжского региона в середине 1930-х гг., была Комиссия партийного контроля (КПК) при ЦК ВКП(б) и ее территориальные структуры - партколлегии, а затем и уполномоченные КПК по Ивановской и Ярославской областям.

Общий вывод, к которому приходит автор: кампания по обмену и проверке партийных документов стала репрезентативной иллюстрацией методологически выверенных политических технологий сталинского режима, о чем свидетельствует ее ход: организованность, полный контроль со стороны центра посредством директив, направляемых ведомствам-исполнителям, результативность, проявившаяся в выявлении «социально чуждых элементов», регистрируемых статистически по линии КПК.

Ключевые слова: партийно-политический контроль, методы и технологии власти, социальная фильтрация, партноменклатура, сталинский режим, Верхнее Поволжье, репрессии.

Кампания по проверке и обмену партийных документов в Советском государстве открылась в мае 1935 г. и формально закончилась только осенью 1936 г. [16, с. 369], когда был возобновлен прием в партию. При этом промежуточные отчеты о ходе интенсивности и результативности проверки проводились регулярно: в июле 1935 г. [30], в декабре 1935 г. (на пленуме ЦК) [16, с. 295], в январе/феврале 1936 г. и в июне 1936 года [17, с. 724,731]. Проверка партдокументов представляла собой масштабную, охватывающую все регионы, идейно-политическую аттестацию - внутрипартийную фильтрацию коммунистов на предмет «политической благонадежности» с помощью тщательного изучения биографических данных, ориентированного на поиск «социально чуждого» происхождения, участия в «антисоветских группировках» или наличия нарушений партийной, государственной дисциплины, партийной этики, профессиональных взысканий.

Все это могло повлечь за собой различные санкции - от перевода в низшие категории «сочувствующих» до исключения из рядов ВКП(б), что означало в большинстве случаев потерю полноценного социального статуса, маргинализацию и превращение человека в наиболее вероятную кандидатуру для дальнейшего политического преследования, что зафиксировано в историографии. Так, О.В. Хлевнюк справедливо считает, что данная кампания представляла собой «смесь традиционной партийной чистки и спецопераций органов НКВД», и тем самым ее можно оце- нить как «новый шаг в эскалации репрессий против членов партии» [38, с. 235]. И.В. Павлова [22], В.3. Роговин [35], А.А. Колдушко [15], через призму деятельности Комиссии партийного контроля (КПК) при ЦК ВКП(б) Т.Н. Никонорова [19] признают проверку партийных документов, инициированную сталинским руководством, составным компонентом «репрессивного цикла»

Зарубежные историки предприняли попытку обратиться к теоретико-методологическим основаниям и функциональной специфике партийных чисток, что можно вполне репрезентативно экстраполировать и на рассматриваемое нами явление. Так, А. Блюм, М. Веспуле довольно подробно освещают технологию чисток в партии, предлагают классификацию «оппозиционного поведения», оценивая общий идеологический принцип функционирования органов контроля как «инструментализацию фактов в репрессивных целях», когда прошлое становится на «службу» у настоящего [3, с. 28, 267].

Б. Штудер и Б. Уинфрид непосредственно затрагивают сам механизм внутрипартийного контроля и его составные звенья - партийные взыскания и социально-политические критерии их наложения на богатом архивном материале. Они приходят к интересным выводам о роли критики и самокритики как «ритуалов партийной жизни», выполнявших функцию политического контроля, направленного на «демонтаж личности», под угрозой исключения из партии как «социальной смерти»-уничтожение исконной идентичности и формиро- 
вание новой «партийной ментальности» [39, c. $10-11,89,125]$. На региональном уровне ход кампании по проверке и обмену партийных документов изучен лишь поверхностно и фрагментарно в работах исследователей-регионоведов, посвященных проблемам динамики партноменклатуры [18], экономической истории [20], а также в рамках истории органов государственной безопасности $[4 ; 12]$.

Все это свидетельствует о недостаточной степени изученности рассматриваемой проблемы, актуальности обращения к этим сюжетам политической истории 1930 -х годов.

Непосредственной целью кампании был сбор компрометирующих материалов на коммунистов и составление «картотеки» потенциально репрессированных. Одним из ведущих институциональных инструментариев, осуществлявших «идеологическую экспертизу» на территории Верхневолжского региона в середине 1930-х гг., была Комиссия партийного контроля (КПК) при ЦК ВКП(б) и ее территориальные структуры - партколлегии, а затем и уполномоченные КПК при ЦК ВКП(б) по Ивановской и Ярославской областям. КПК представляла собой коллегию судебно-следственного типа, занимавшуюся проверкой выполнения решений ЦК ВКП(б) и СНК СССР партийными и советскими структурами. Она возникла в феврале 1934 г. как институциональный правопреемник объединенного наркомата ЦКК (Центральная контрольная комиссия) - НК РКИ (Рабоче-крестьянская инспекция), формально унаследовавший внугрипартийные функции секции ЦКК $[27$, л. 45-47], но в реальности приобретший более широкие полномочия и занявший исключительное положение в политической системе СССР как один из ведущих инструментов-проводников воли «генеральной линии партии», что было санкционировано самим И.В. Сталиным.

Запуск внутрипартийного мониторинга на территории еще тогда Ивановской промышленной области (ИПО, существовала в 19291936 гг.) был осуществлен закрытым письмом ЦК ВКП(б) «О беспорядках в учете, выдаче, хранении партбилетов и о мероприятиях по упорядочению этого дела» от 13 мая 1935 г. [5, л. 2-3; 2, л. 3-6], которое поступило на имя ответственного секретаря партколлегии КПК по ИПО А.Ф. Витковского. Но архивные до- кументы, данные региональной периодической печати свидетельствуют, что уже начиная с января 1935 г. внутрипартийный контроль тщательно готовился к этому важнейшему идейно-политическому мероприятию, инициировав предварительный зондаж умонастроений населения Верхневолжского региона и его руководителей. Партколлегия (далее- ПК) КПК по ИПО контролировала уровень проведения организационно-пропагандистских кампаний, а также не менее внимательно относилась к случаям «персональных извращений». Ответственный секретарь ПК КПК А.Ф. Витковский был крайне обеспокоен медлительностью городских партийных организаций - горкомов и горрайкомов области - в мобилизации кадрово-технического корпуса, необходимого для предстоящей чистки. «Костромской горком, - писал он И.П. Носову, - запрашивает ПК, возможно ли начинать подбор технического аппарата для чистки. Это означает отсутствие всякой работы в этой области». Далее приводились выдержки из ответа заместителя секретаря городского комитета (далее - ГК) ВКП(б) Кузнецова, признанного невразумительным, который, как констатировал Витковский, судя по содержанию, «сигнализирует об искривлениях, уже имеющих место в горкоме» $[24$, л. 28]. Аналогичные оценки были перенесены на партийные организации Владимира и Ярославля.

На некоторые промышленные объекты выехали со специальной проверкой партследователи. Они должны были выяснить, насколько политические настроения на предприятиях соответствуют очередным идеологическим установкам, а также оперативно обработать поступившие сигналы. Один из таких сигналов бдительности поступил из парткома ковровского оружейного завода ИНЗ № 2, где рабочий Новоселов выступил с «контрреволюционными заявлениями», высказав предположение, что директор завода Савельев поехал на VII Съезд Советов только потому, что «купил бутылку водки секретарю обкома тов. Носову». А по поводу смерти В.В. Куйбышева он имел неосторожность пошутить, что тот умер от пьянства [24, л. 42].

На парткоме эти слова были однозначно квалифицированы как «выступление классового врага, желающего опорочить руководи- 
телей и партию» [24, л. 44]. Прибывшему на завод члену ПК КПК М.М. Магдюку удалось установить, что Новоселов - бывший унтерофицер, «замаскированный двурушник», а также в ходе комплексной проверки выявить еще более 40 «социально-чуждых элементов, скрывавших свое происхождение» [24, л. 42]. Подобный материал, благоприятный для дальнейшей разработки, был обнаружен и на кинешемской фабрике «Приволжская коммуна», что было напрямую связано с ошибками бывшего и недавно снятого руководства. Как выяснилось, Кинешемский ГК и Наволокский районный комитет (далее - РК) ВКП(б) не только не обеспечили «коренной перестройки работы партийной организации», но и «вновь проглядели» состояние районных хозяйственно-политических объектов, которые оказались «засоренными врагами народа». Из переписки И.П. Носова с А.Ф. Витковским: «вскрылось, что «самокритика на фабрике зажата со стороны директора, практикующего разного рода подачки части партактива, что породило в парторганизации элементы загнивания, примиренчества и круговой поруки, при которой антипартийные действия руководства на фабрике не только не разоблачались, но и всячески замазывались» [24, л. 146].

В феврале 1935 г. в Ярославском медицинском техникуме была вскрыта и ликвидирована «контрреволюционная террористическая группировка», возглавляемая комсомольцем Дурыниным и студентами Орлеанским и Парфеновым. Эта группа «обсуждала вопрос о проведении террора против вождей партии, причем приняла решение после предварительной подготовки выехать в Москву, связаться с другими террористическими организациями и совершить террористический акт» [36, л. 20].

В связи с этим летом-осенью партколлегией КПК были подтверждены исключения из партии, осуществленные Ярославским ГК ВКП(б), доцента Яролавского пединститута К.И. Защинского, поддерживающего «систематическую связь с контрреволюционной троцкистско-зиновьевской оппозицией», студента сельскохозяйственной школы А.И. Крюкова за «двурушнические и хвостистские настроения», преподавателя истории партии Пошехоно-Володарского рабфака С.П. Градова, «не отражавшего в даваемых студентам опросниках борьбу с троцкизмом», Рыбинским ГК ВКП(б) - сотрудника городского отдела народного образования (гороно) Короткова за «притупление классовой бдительности и недостаточное руководство школами» [13, л. 12-14]. Был исключен из партии инженер, аспирант Рыбинского авиаинститута А.М. Волков, пришедшеий к «контрреволюционному выводу», говоря: «У нас нет перспектив развития, мы держимся обманом и эксплуатацией рабочих, разоряем крестьянство. Вся страна идет к гибели. В партии нет демократии, бюрократическая верхушка зажала рядовую партийную массу» [13, л. 12-13].

Аналогичная волна прокатилась и по Ивановской, Владимирской, Костромской партийным организациям. Это дела студента Ивановского химинститута А.П. Григорьева, преподавателя-консультанта по истории партии Касаткина, работников Костромского парткабинета Попова и Волкова, исключенных из партии за то, что к 11-й годовщине смерти В.И. Ленина на витрину выставки книг поставили работу Г. Зиновьева «Шесть дней» [6, л. 52]. Все парткабинеты области испытали на себе ударную волну, накрывшую их после обнаружения «недостаточной идеологической настороженности» в одном из них $[1$, л. 92].

Важным компонентом подготовки к кампании по обмену партийных документов была проверка состояния учетных карточек коммунистов на предмет точного отображения всех взысканий, вынесенных бюро КПК по представлению региональных партколлегий за период с сентября 1934 г. по январь 1935 года. В качестве основания для проверки приводились неутешительные статистические данные по Москве, пример которой должен был воодушевить региональные ПК на педантичную исполнительность в этом вопросе. По Москве из 110 партвзысканий, вынесенных бюро КПК, своевременно были занесены в учетные карточки только 67 коммунистам, 23 были записаны только в момент проверки ПК по Московской области, и местонахождение 20 человек из выбранного перечня - неизвестно [25, л. 47-48].

Таким образом, на этих примерах мы видим, что органы внутрипартийного контроля заблаговременно обеспечивали себе информационно-политический приоритет, что в 
дальнейшем, уже в ходе самой кампании по проверке партдокументов, позволило без труда делать «нужные выводы», опираясь на сведения, которые поступали отовсюду, начиная от обкома и заканчивая низовыми партийными организациями.

Прологом, по настоящему вселившим уверенность в Витковского и побудившего его на верноподданническую активность, стало так называемое дело Ивановского горкома ВКП(б) и его первого секретаря Б.П. Соколинского. Начало этому делу было положено весной-летом 1935 г., а затем оно превратилось в «сквозную линию», лейтмотив, ключевое звено, выражаясь языком тех лет, - в «контрреволюционную колыбель», к которой сталинское руководство неоднократно возвращалось, желая продемонстрировать глубокие истоки «оппортунизма» верхневолжских партийцев. Здесь в очередной раз отчетливо проявилась сигнализаторская функция «Правды», в которой в ряде статей, появившихся в печати еще до начала кампании проверки документов 27 марта [28], 7 апреля [29], а затем регулярно воспроизводящих типовые претензии в публикациях от 26 августа 1935 г. [31], марте и июне 1936 г. [32], возвещалось о «неблагополучном» положении в Ивановской области. Соколинского критиковали за отсталость партийной работы, пришедшей в упадок из-за его «зазнайства и самоуспокоенности» как секретаря парторганизации, в результате бездеятельности которого были «вскрыты вопиющие факты нарушения внутрипартийной демократии и отсутствие революционной бдительности», следствием которой стала хроническая «засоренность аппарата горкома чуждыми элементами» [11, л. 123-127].

А.Ф. Витковский специально запрашивал обком и лично И.П. Носова, требуя предоставить стенограммы выступлений Соколинского на пленумах Ивановского ГК ВКП(б), чтобы почерпнуть нужную информацию о его «политической физиономии» [24, л. 333]. На пике критики Соколинского вышло постановление ЦК ВКП(б) «Об ошибках Саратовского крайкома ВКП(б)», датированное 23 июня 1935 г. и через месяц перепечатанное в региональных газетах. Оно угрожающе гласило: «Саратовский крайком ВКП(б) грубо нарушил линию партии в деле воспитания и выращива- ния кадров, допустив в отношении кадров переадминистрирование, выразившееся в массовых смещениях и партийных репрессиях вместо систематической работы по воспитанию кадров» [23, с. 44]. Главной причиной такой «запущенности партийного хозяйства», по мнению центрального руководства, стала недопустимая практика занижения авторитета и правомочий органов партийного контроля, проводившееся «под прикрытием необоснованных разговоров о двоецентрии».

Таким образом, ЦК выразив публичное недоверие сложившейся конкретной модели взаимоотношения местного руководства и КПК, не только создал необходимый прецедент для ее беспрепятственной работы по составлению «сталинских списков», но и фактически предрешил судьбу руководителей этого уровня. На этой волне и проводилась кампания по обмену партийных документов в области, открывая которую, ЦК ВКП(б) предупреждал о недопустимости ее мимолетно-сезонного характера, призывая к систематической и неутомимой борьбе на «пропагандистском фронте». [23, с. 43]. Результаты не заставили себя ждать. В июне-июле 1935 г. партколлегией КПК по ИПО совместно с НКВД были вскрыты две контрреволюционные организации в редакции газеты «Рабочий край», в состав которой входили заместитель редактора Сибирякова, фоторепортеры Готовкин, Хломов, Камайданов, Буров, Сархин и др. Из материалов партколлегии выяснилось, что «участники устраивали систематические сборища, на которых давали контрреволюционную оценку мероприятиям советской власти и партии, ставили перед собой задачу захвата руководства газеты в антисоветских целях». $[13$, л. 4].

Уже эти данные позволили в июле 1935 г. Н.И. Ежову в докладной записке на имя И.В. Сталина отметить желаемую динамику. «Новым в ходе проверки партийных документов, - coобщал председатель КПК, - за последнее время в части выявления врагов народа является то, что со всей очевидностью вскрываются не только отдельные люди, обманным путем проникшие в ВКП(б), но и целые организации... В этом отношении особенно показательны троцкистские образования. Они вскрыты во многих местах Украины, Казах- 
стана, Иваново-Вознесенска (курсив здесь и далее мой. $-K$. Ю.), Красноярска и других организаций...» [26, с. 244]. А в докладе, сделанном в декабре 1935 г. на пленуме ЦК, Ежов заявил, что данные по Ивановской области являются наиболее «типичными», поскольку там «без решения ГК и РК выдано 6500 партбилетов», а «политические ошибки» уходят корнями в начало 1930-х гг., ибо «в основе нарушения устава партии лежит решение Ивановского обкома от 21 ноября 1931 г., согласно которому обком предоставил многим партийным комитетам право окончательного решения о приеме в партию без утверждения обкома» [7, л. 36].

Архивные документы КПК свидетельствуют о реальном объеме собранных «компрометирующих материалов». В августе 1935 г. заместитель начальника управления НКВД по ИПО В.А. Стырне сообщал Витковскому, что «в связи с проверкой партийных документов арестованы 89 человек (троцкистов -10 , антипартийных элементов -14 , шпионов -1 , диверсантов -2 , провокаторов -2 , участников бело-зеленых армий -9 , аферистов - 33, скрывавших свое происхождение 4, др. - 14)». «Начальникам местных аппаратов, - продолжал он, - переданы все имеющиеся компрометирующие материалы на членов и кандидатов ВКП(б): секретарям Ивановского ГК передано 2 списка на 200 человек, Ярославского ГК - на 212, Рыбинскому на 103, Вичужскому РК - на 59 человек, Кинешемскому - на 36, Мышкинскому - на 60 человек» [37, л. 5]. Летом 1935 г. аналогичные материалы были получены и по Владимирскому району, в райком которого поступило «свыше 150 устных и письменных заявлений от коммунистов, сообщивших те или иные данные, компрометирующие и вскрывающие настоящее лицо некоторых пребывающих в партии людей» [14, л. 57].

Правоту Ежова был вынужден признать и первый секретарь Ивановского обкома И.П. Носов, подтвердивший приведенные в докладепредседателя КПК цифры и сделанные выводы из этого: «члены партии, находившиеся в течении 3-4 лет в партии, должны быть исключены из нее как принятые не по Уставу» [34].

Чувствуя дальнейшую срочную необходимость «оправдаться» перед вышестоящим руководством за «притупление политической бдительности», 27 февраля 1936 г. обком ИПО подготовил обширный отчет. В нем приводился список, в котором исключенные 14,1 \% коммунистов делились на 24 основные категории. Среди них фигурировали: 5 «чуждых людей и пробравшихся в партийный аппарат и использовавших его для получения партдокументов» (4 члена партии, 1 - кандидат. Далее - 4/1 и т. д.); «обманным путем получивших партдокументы (подделки под видом утери, хищения)» - 56 чел. (43/13); «подозреваемые в шпионаже» - 33 чел. (29/4); «троцкистов и зиновьевцев» - 307 чел. (294/13); «аферистов и жуликов» - 346 чел. (258/88); «белогвардейцев» 175 чел. (145/30); «участников контрреволюционных кулацких восстаний» - 232 чел. (174/58); «полицейских, урядников, жандармов и прочих, служивших в полиции» - 84 чел. (73/11); «детей полицейских» - 307 чел. (240/67); «кадетов, эсеров, меньшевиков и выходцев из других партий» - 132 чел. (115/17); «черносотенцев» -41 чел. $(36 / 5)$; «кулаков и выходцев из кулацкой среды» - 848 чел. (589/259); «торговцев и выходцев из торгашеской среды»757 чел. (561/196); «заводчиков, фабрикантов и выходцев из этой среды» - 145 чел. (110/35); «дворян, помещиков и выходцев из этой среды» - 44 чел. (36/8); «служителей религиозного культа, церковников, сектантов» 177 чел. (125/52); «прочих социально чуждых элементов и связанных с социально-чуждыми элементами» - 902 чел. (635/267); «преступников, судившихся ранее за различные преступления (растраты, хищения социалистической собственности и другие злоупотребления)»- 1229 чел. (880/349); «разложившихся элементов (пьянство, бытовое разложение, распущенность)»-2 380 чел. (1700/680); «не прошедших чистку 1929 года»-73 чел. (64/19); «ранее исключенных из партии, но состоявших на учете в партийной организации» - 104 чел. (60/44); «принятых с нарушением устава»337 чел. (209/128); «оторвавшихся от партии и потерявших связь с партией» - 3452 чел. (1117/1735); «исключенных по другим причинам» - 425 чел. (116/309).

Далее приводились текущие «оперативные данные» и практические меры, принятые в отношении части лиц, «уличенных» в «контрреволюционных вылазках». Всего из 77 рай- 
онов области (ИПО) «троцкисты-зиновьевцы» были обнаружены в 51: в Иванове - 46 чел., в Ярославле - 45 чел., в Костроме - 13 чел., в Рыбинске - 13 чел., в Вичуге - 11 чел., во Владимире - 11 чел., в Александрове - 6 чел., в Гусь-Хрустальном - 4 человека. Как указывалось, на тот момент (к концу 1935 г. началу 1936 г.) было уже арестовано 319 чел., привлечено к судебной ответственности без ареста - 71 чел. Из них: «чуждых» людей, проникших в партаппарат, -3 чел., троцкистовзиновьевцев - 103 чел., аферистов и жуликов 51 чел., белогвардейцев и кулаков - 116 чел., шпионов -5 чел., провокаторов -5 чел., по другим причинам - арестованы 36 чел. Из общего количества привлеченных к судебной ответственности и арестованных на 27 февраля осуждено 147 чел. За 1936 г. эти «прогнозы по разоблачениям» неоднократно подтверждались еще более внушительной статистикой, масштабы которой были вызваны под влиянием атмосферы так называемого первого «московского процесса» августа 1936 г. над «антисоветским террористическим троцкистско-зиновьевским центром».

За период проверки партийных документов было исключено: «троцкистов-зиновьевцев» - 250 чел., «белогвардейцев и кулаков» 755 чел., «жуликов и аферистов» - 152 чел., «за связь с чуждыми элементами» - 360 чел. И только по Ивановской области было вскрыто 33 «контрреволюционные группы», из них 25 - при проверке и 8 - при обмене партийных документов (в Иванове, Владимире, Александрове, Собинке, Коврове, Кинешме, Вичуге, Кольчугине, Родниках; в парторганизациях: Комсомольской, Середской, Вязниковской, Тейковской, Шуйской, Гороховецкой, Меленковской» [21, л. 2-4, 54-58].

Из всех дел, проходивших по линии КПК и НКВД в это время, наиболее примечательны случаи детальной проработки «партийной интеллигенции» - руководителей органов периодической печати, парткабинетов, отделов образования и т. д. В них, помимо общих критериев, очевидно, видели наиболее вероятных «контрреволюционеров», владеющих определенными теоретическими знаниями и навыками обращения с ними. Тем самым они попадали под категорию особенно неблагонадежных с высоким «индексом враждебнос- ти». Так, уже летом 1935 г., в самый разгар кампании по обмену партдокументов, судя по архивным данным, партколлегия КПК открыла атаку против редакции областной газеты «Рaбочий край». В информационном донесении в центр говорится следующее: «По поручению отдела печати и издательства ЦК ВКП(б) партколлегия расследовала заявление Лешукова против редактора областной газеты 3.Д. Ефанова. Установлено, что в редакции "Рабочего края" свила себе гнездо явно контрреволюционная группа, сохранявшаяся там длительное время благодаря политической близорукости и отсутствию большевистской бдительности среди коммунистов аппарата редакции. В июле 1935 г. органами НКВД по ИПО были вскрыты и ликвидированы две, связанные между собой к-р группы, приютившиеся в стенах редакции "Рабкрая", в состав которых входили фоторепортеры и литературные работники редакции: ГОТОВКИН - сын торговца, ХЛОМОВ - сын купца, ранее репрессировавшийся органами ОГПУ и судился; КАМАЙДАНОВ - сын торговца; БУРОВ художник - судился; САРУИН - сын торговца за хулиганство и др. Участники группировок устраивали систематические сборища, на которых давали к-р оценку мероприятиям советской власти и партии. Допускали гнусные выпады против вождей ВКП (б) и советской власти. Писали и рисовали антисоветские произведения... Группа фоторепортеров обсуждала вопрос о приобретении оружия. В газете помещались неправильные материалы, в которых защищались позиции классового врага...» [13, л. 2-3].

Другим, не менее примечательным, делом, характеризующим обстановку тех лет, стал случай с заведующим районным отделом образования в г. Владимире (районо) Зворыкиным, обвиненным в «идеологических извращениях». Выяснилось, что Зворыкин «был эсером и активным участником муромского контрреволюционного восстания», тем самым «продолжил борьбу с партией, вращаясь среди партийного актива Владимирской организации», развязно издевался над партийным руководством, облекая все это в форму циничных шуток, анекдотов, причем вся эта пошлость имела ярко выраженный троцкистско-зиновьевский, по существу, контрреволюци- 
онный характер. Например, при осмотре резолюции, принятой на митинге, посвященном памяти т. Куйбышева, Зворыкин заявляет, что он «составил “аполитичную резолюцию”, так как забыл сплотить ряды вокруг ЦК» $[13$, л. 7]. Для нас важно отметить, что дело Зворыкина стало одним из звеньев в цепи политических претензий к Владимирскому району. Вскоре для расследования «зворыкинского следа» туда прибыл сотрудник КПК [33, л. 157]. В результате политическая атмосфера Владимирского района была подвергнута серьезной «идеологической экспертизе», по итогам которой был сделан обобщающий вывод: «В результате проверки партдокументов вскрыта засоренность Владимирской парторганизации троцкистско-зиновьевскими охвостьями, классово-враждебными элементами из помещиков, купцов, торговцев, спекулянтов, подрядчиков, [а также] жуликами, аферистами и морально-разложившимися элементами... Эта контрреволюционная группа имела ответвления в гусевском уезде (Бугров, Волков, Егоров), в Муроме, Вязниках, Кольчугине, а также во Владимирском гарнизоне (Галушин, Петров, Фонарев) [14, л. 6-7].

Все это было объединено в единый «очаг контрреволюции», существовавший в ГусьХрустальном, Муроме, Вязниках, Владимире. В специальной докладной записке, посвященной первичным итогам проверки партдокументов и составленной, очевидно, летом 1935 г., говорилось: «Гусевским РК вскрыто, [что] в 1927 г. в Гусь-Хрустальном на заводе им. Бухарина была организована "группа одиннадцати”, которая вела борьбу против повышения норм выработки, фактически, возглавляла происходившую на заводе забастовку, всяческими путями стараясь вызвать недовольство и возмущения рабочих». Организатором существовавшей в 1927-1929 гг. «группы одиннадцати», якобы претендовавшей уже не только на внутрирегиональный, но и даже общесоюзный масштаб «контрреволюционной деятельности», являлся А.И. Рябов, входивший в «гусевский центр троцкистов», в котором «состояли Рябов, Бугров (работник агитпрома укома), Обухов Яков, Тренин (директор стеклозавода “Красное эхо")» [9, л. 3].

Летом 1936 г. была обнаружена «контрреволюционная группа» в газете «Северная правда» [8, л. 4], а в самом конце 1936 г. городским отделом (ГО) НКВД г. Костромы было сфабриковано дело об «антисоветской группе» на заводе катеростроения. В докладной записке, составленной оперуполномоченным секретно-политического отдела (СПО) НКВД Меркудиновым сообщалось, что на обозначенном заводе «за последние два года крепко осела группа лиц, явно морально-разложившихся элементов, которая до настоящего времени продолжает творить свои антигосударственные делишки: самоснабжение, шкурнические махинации, взяточничество, подхалимство». В числе лиц, входивших в эту группу, были названы: директор завода Маковский, технорук В.А. Флоров, бухгалтер Бочикалов, начальник снабжения Соколов, агент по снабжению Ф.Д. Карезин, техниккалькулятор Роднов, плановик Кульков, кассир В.А. Соболева [10, л. 12].

Список приведенных примеров можно продолжить. Таким образом, мы видим, что кампания по проверке и обмену партийных документов, будучи тщательно спланированным мероприятием, стала важнейшим этапом по утверждению сталинской диктатуры и отражением политических технологий советского тоталитаризма 1930-х гг., основывающихся на практиках насаждения релятивизма и энтропийности мышления - метода «контролируемого хаоса» - распыления социальной энергии в нужную сторону, целенаправленного стравливания «своих» и «чужих». Это презентовалось как очередная веха «классовой борьбы», неисчерпаемая конфронтация между представителями «старого режима» - царизма или широкого спектра «оппортунистовдвурушников», обнаруженных среди членов партии и - «прогрессивного» партийного аванганда, большинства. В ходе интенсивного изучения «политической физиономии» отдельныХ лиц и целых социально-экономических объектов применялся метод информационно-когнитивной диверсии - подмены объективной оценки реальности и действий ее участников партийной догматикой, господствующим «дискурсом» коммунистической идеологии, непрерывность и эффективность воздействия которого обеспечивалась максимальной политизацией повседневности. Поэтому все это можно рассматривать как своеобразную «онтоло- 
гическую режиссуру» [40], сопровождавшуюся увереннным утверждением монополии на «истину», единственным источником которой выступала воля «генеральной линии партии» и олицетворявшего ее И.В. Сталина.

Поэтому совместными усилиями КПК и НКВД, игравших на правах взаимосвязанных партнеров роль координаторов и исполнителей репрессивных атак, абсолютно любой человек мог быть объявлен «социальночуждым элементом», «врагом народа», поскольку истолкование его деятельности в настоящем или прошлом, и степень «виновности» зависели только от текущих требований политической конъюнктуры. Кампания по проверке партдокументов позволила собрать солидный «компрометирующий материал» против партийной и советской номенклатуры Ивановской, Ярославской областей и ее компонентов, использовавшийся в дальнейшем для фальсификации дел о «контрреволюционных заговорах» против руководителей партии и правительства в период «большого террора» 1937-1938 гг., когда были расстреляны секретари Ивановского обкома ВКП(б) Н.Н. Колотилов, И.П. Носов, В.Я. Симочкин, Ярославского - А.Р. Вайнов, Н.Н. Зимин и многие другие руководящие работники. Сама кампания носила предельно инструментальный, строго ограниченный в хронологическом отношении характер, что было обусловлено прагматическими целями и методами политического контроля сталинского режима, чередовавшего репрессивные атаки с кратковременными поворотами к «рациональной стабилизации», как правило, предшествовавшей новой волне террора, что и произошло на рубеже 1936-1937 годов.

\section{СПИСОК ЛИТЕРАТУРЫ}

1. Анализ работы парткабинетов по организации партийного просвещения в районах Ивановской промышленной области. Март 1935 г. // Государственный архив Ивановской области (ГАИО). Ф. П-287. - Оп. 1.- Д. 76.

2. Андрей Федорович Витковский. Личное дело. 1935 г. // ГАИО. - Ф. П-327. - Оп. 5. - Д. 852.

3. Блюм, А. Бюрократическая анархия: статистика и власть при Сталине / А. Блюм, М. Веспуле. М. : РОССПЭН, 2006. -328 c.
4. Верой и правдой: ФСБ. Страницы истории / упр. ФСБ по Ярославской обл. ; ред. совет: А. А. Котельников [и др.]. - Ярославль : Нюанс, 2001. - 528 с.

5. Витковский Андрей Федорович. Личное дело за 1934 г. // ГАИО. - Ф. П-327. - Оп. 2. - Д. 3422.

6. Выписки из протоколов заседаний Оргбюро ЦК ВКП(б) по Ярославской области, КПК при ЦК ВКП(б), Костромского горкома ВКП(б). 4 февраля 1936- 11 января 1937 г. // ГАНИКО. - Ф. П-2. Оп. 1. - Д. 376.

7. Доклад и выступления Н.И. Ежова на пленуме ЦК ВКП(б). Декабрь 1935 г. // РГАСПИ. Ф. 671. - Оп. 1. -Д. 11.

8. Докладные записки в Оргбюро ЦК ВКП(б) об итогах обмена партийных документов. 1936 г. // Государственный архив новейшей истории Костромской области (ГАНИКО).-Ф. П-2. -Оп. 1. - Д. 347.

9. Докладные записки горкомов и райкомов об итогах обсуждения закрытого письма ЦК ВКП(б) от 13 мая 1935 г. «О беспорядках в учете, выдаче и хранении партийных билетов, и мероприятиях по упорядочению этого дела» в городских и районных партийных организациях Ивановской области. 1935 г. // ГАИО. - Ф. П-327. - Оп. 5. - Д. 569.

10. Докладные записки Костромского горкома ВКП(б) и специальные донесения городского отдела НКВД. Декабрь 1936 - 28 сентября 1937 г. // ГАНИКО. - Ф. П-2. - Оп. 1. - Д. 348.

11. Докладные записки ответственных контролеров аппарата уполномоченного КПК при ЦК ВКП(б) по Ивановской области. Июль 1936 - декабрь 1937 г. // ГАИО. - Ф. П-367. - Оп. 1. - Д. 158.

12. Из истории органов государственной безопасности в Ивановской области. 1918-1954 гг. - Иваново, 2008. $-470 \mathrm{c}$.

13. Информация о работе партколлегии КПК при ЦК ВКП(б) по Ивановской области. 1935 г. // ГАИО. -Ф. П-367. - Оп. 1. - Д. 65.

14. Итоги проверки партийных документов у членов и кандидатов ВКП(б). Октябрь 1935 г. // ГАИО. Ф. П-367. - Оп. 1. - Д. 63.

15. Колдушко, А. А. Номенклатура в истории советского общества / А. А. Колдушко. - Электрон. текстовые дан. - Режим доступа: http://elis.pstu.ru/ index.php?a=9\&pod_id=31\&pod3_id=113\#_edn4 (дата обращения: 02.03.2016). - Загл. с экрана.

16. Коммунистическая партия Советского Союза (КПСС) в резолюциях, решениях съездов, конференций и пленумов ЦК. - М. : Политиздат, 1985. T. 7. $-576 \mathrm{c}$.

17. Лубянка. Сталин и ВЧК-ГПУ-ОГПУ-НКВД. Архив Сталина. Документы высших органов партийной и государственной власти. Январь 1922 декабрь 1936. - М. : Материк, 2003. - 912 с.

18. Михалищев, Р. А. Ярославская партийная номенклатура: структура и динамика (1936- 
$1939)$ : материалы Всерос. науч. конф., посвященной 200-летию Ярославского государственного университета им. П.Г. Демидова. - Ярославль, 2003. - C. $173-176$.

19. Никонорова, Т. Н. Комиссия партийного контроля при ЦК ВКП(б) (1934-1952 гг.) // Российская история. - 2015. - № 6. - С. 26-40.

20. Околотин, В. С. Ивановская промышленная область в 1929-1936 гг. Уроки экономической истории / В. С. Околотин. - Иваново : ИГТА, 2009. $528 \mathrm{c}$.

21. Отчет в ЦК ВКП(б) о работе Ивановского обкома партии за 1936 г. Январь - декабрь 1936 г. // ГАИО. - Ф. П-327. - Оп. 5. - Д. 1078.

22. Павлова, И. В. Механизм власти и строительство сталинского социализма. Новосибирск : CO PAH, 2001. $-460 \mathrm{c}$.

23. Партийное строительство. - 1935. - № 13.

24. Переписка партколлегии с партийными и комсомольскими организациями. 3 мая - 29 декабря 1935 г. // ГАИО. - Ф. П-367. - ОП. 1. - Д. 103.

25. Переписка с ЦК ВКП(б) и Комиссией партийного контроля при ЦК ВКП(б) по вопросам организационно-партийной работы и о кадрах. 1 января - 20 декабря 1935 г. // ГАИО. - Ф. П-327. Оп. 5. - Д. 518.

26. Петров, Н. «Сталинский питомец»-Николай Ежов / Н. Петров, М. Янсен. - М. : РОССПЭН, 2008. -447 c.

27. Положения о Комиссии партийного контроля при ЦК ВКП(б). 1934 г. // Российский государственный архив социально-политической истории (РГАСПИ). - Ф. 17. - ОП. 3. - Д. 940.

28. Правда. - 1935. - 27 марта.

29. Правда. $-1935 .-7$ апр.

30. Правда. $-1935 .-27$ июля.

31. Правда. $-1935 .-26$ авг.

32. Правда. $-1936 .-25$ июня.

33. Протоколы партколлегии Комиссии партийного контроля при ЦК ВКП(б) по Ивановской области. 28 августа - 29 декабря 1934 г. // ГАИО. Ф. П-367. - Оп. 1. - Д. 2.

34. Рабочий край. $-1936 .-8$ янв.

35. Роговин, В. 3. Сталинский неонэп / В. 3. Роговин. - М. : Москва, 1995. - 382 с.

36. Справки, докладные записки Ивановского обкома ВКП(б) о проработке закрытого письма ЦК ВКП(б) «Уроки событий, связанных со злодейским убийством тов. Кирова», о перестройке парторганов, реализации решений ноябрьского пленума ЦК ВКП(б) 1934 г., об отмене карточной системы. 8 февраля 1934 - 10 февраля 1935 гг. // ГАИО. Ф. П-327. - ОП. 5. - Д. 355.

37. Справки НКВД СССР об аресте врагов народа и копии протоколов допросов. Август - октябрь 1935 г. // ГАИО. - Ф. П-367. - ОП. 1. - Д. 68.
38. Хлевнюк, О. В. Хозяин. Сталин и утверждение сталинской диктатуры / О. В. Хлевнюк. - М. : РОССПЭН, 2010. - 479 c.

39. Штудер, Б. Сталинские партийные кадры. Практика идентификации и дискурса в Советском Союзе 1930-х гг. / Б. Штудер, Б. Уинфрид. -М. : РОССПЭН, 2011.-247 c.

40. Юдин, К. А. Репрессивная политика в отношении научно-педагогической интеллигенции в 1930-е гг.: методы и практика / К. А. Юдин // Интеллигенция и мир. - 2014. - № 4. - С. 56-73.

\section{REFERENCES}

1. Analiz raboty partkabinetov po organizatsii partiynogo prosveshcheniya $\mathrm{v}$ rayonakh Ivanovskoy promyshlennoy oblasti. Mart $1935 \mathrm{~g}$. [Analysis of Party Cabinets' Work on the Organization of Party Education in the Districts of the Ivanovo Industrial Region. March 1935]. Gosudarstvennyy arkhiv Ivanovskoy oblasti [State Archive of the Ivanovo Region], F. P-287, Op. 1, D. 76 .

2. Andrey Fedorovich Vitkovskiy. Lichnoe delo. 1935 g. [A.F. Vitkovsky. Personal File. 1935]. Gosudarstvennyy arkhiv Ivanovskoy oblasti [State Archive of the Ivanovo Region], F. P-327, Op. 5, D. 852.

3. Blyum A., Vespule M. Byurokraticheskaya anarkhiya: statistika $i$ vlast pri Staline [Bureaucratic Anarchy: Statistics and Power under Stalin]. Moscow, ROSSPEN Publ., 2006. 328 p.

4. Kotelnikov A.A., ed. (et al.) Veroy i pravdoy: FSB. Stranitsy istorii [Faithfully and Loyally: FSS. Pages of History] Yaroslavl, Nyuans Publ., 2001. 528 p.

5. Vitkovskiy Andrey Fedorovich. Lichnoe delo za 1934 g. [A.F. Vitkovsky. Personal File. 1934]. Gosudarstvennyy arkhiv Ivanovskoy oblasti [State Archive of the Ivanovo Region], F. P-327, Op. 2, D. 3422.

6. Vypiski iz protokolov zasedaniy Orgbyuro TsK VKP(b) po Yaroslavskoy oblasti, KPK pri TsK VKP(b), Kostromskogo gorkoma VKP(b). 4 fevralya 1936 11 yanvarya $1937 \mathrm{gg}$. [Extracts from the Minutes of Meetings of the Central Committee of the Organising Bureau of the CPSU (b) in the Yaroslavl Region, the CPC Central Committee under the CPSU (b), the Kostroma City Committee of the CPSU(b). February4, 1936 - January 11, 1937]. Gosudarstvennyy arkhiv noveyshey istorii Kostromskoy oblasti [State Archive of Contemporary History of the Kostroma Region], F. P-2, Op. 1, D. 376.

7. Doklad i vystupleniya N.I. Ezhova na plenume TsK VKP(b). Dekabr 1935 g. [The Report and Speeches by N.I. Ezhov at the Plenum of the Central Committee of the CPSU (b). December 1935]. Rossiyskiy gosudarstvennyy arkhiv sotsialno-politicheskoy istorii [Russian State Archive of Socio-Political History], F. 671, Op.1, D. 11. 
8. Dokladnye zapiski v Orgbyuro TsK VKP(b) ob itogakh obmena partiynykh dokumentov. $1936 \mathrm{~g}$. [Memoranda in Orgburo of Central Committee CPSU (b) on the Outcome of Party Documents Exchange. 1936]. Gosudarstvennyy arkhiv noveyshey istorii Kostromskoy oblasti [State Archive of Contemporary History of the Kostroma Region], F. P-2, Op. 1, D. 347.

9. Dokladnye zapiski gorkomov i raykomov ob itogakh obsuzhdeniya zakrytogo pisma TsK VKP(b) ot 13 maya $1935 \mathrm{~g}$. «O besporyadkakh v uchete, vydache i khranenii partiynykh biletov, i meropriyatiyakh po uporyadocheniyu etogo dela» v gorodskikh i rayonnykh partiynykh organizatsiyakh Ivanovskoy oblasti. 1935 g. [Reports of the City and District Committees on Deliberations of Private Letter of the Central Committee of the CPSU (b) of May 13, 1935 "On the riots in accounting, distribution and storage of party tickets, and activities to streamline the case" in the City and District Party Organizations of the Ivanovo Region. 1935]. Gosudarstvennyy arkhiv Ivanovskoy oblasti [State Archive of the Ivanovo Region], F. P-327, Op. 5, D. 569.

10. Dokladnye zapiski Kostromskogo gorkoma VKP(b) i spetsialnye doneseniya gorodskogo otdela NKVD. Dekabr 1936 - 28 sentyabrya 1937 g. [Reports of the Kostroma City Committee of the CPSU (b) and the Special Reports of the City Department of the NKVD. December 1936 - September 28, 1937]. Gosudarstvennyy arkhiv noveyshey istorii Kostromskoy oblasti [State Archive of Contemporary History of the Kostroma Region], F. P-2, Op. 1, D. 348.

11. Dokladnye zapiski otvetstvennykh kontrolerov apparata upolnomochennogo KPK pri TsK VKP(b) po Ivanovskoy oblasti. Iyul 1936 - dekabr 1937 g. [Reports of the Controllers Responsible to the Commissioner CPC at the the CPSU (b) in the Ivanovo Region. July 1936 - December 1937]. Gosudarstvennyy arkhiv Ivanovskoy oblasti [State Archive of the Ivanovo Region], F. P-367, Op. 1, D. 158.

12. Iz istorii organov gosudarstvennoy bezopasnosti v Ivanovskoy oblasti. 1918-1954 gg. [From the History of the State Security Bodies in the Ivanovo Region. 1918-1954]. Ivanovo, 2008. 470 p.

13. Informatsiya o rabote partkollegii KPK pri TsK VKP(b) po Ivanovskoy oblasti. $1935 \mathrm{~g}$. [Information about the Work of the Party Collegium CPC at the the CPSU (b) in the Ivanovo Region. 1935]. Gosudarstvennyy arkhiv Ivanovskoy oblasti [State Archive of the Ivanovo Region], F. P-367, Op. 1, D. 65.

14. Itogi proverki partiynykh dokumentov u chlenov i kandidatov VKP(b). Oktyabr 1935 g. [The Results of Party Documents Verification of Members and Candidates of the CPSU (b). October 1935]. Gosudarstvennyi arkhiv Ivanovskoi oblasti. [State Archive of the Ivanovo region], F. P-367, Op. 1, D. 63.
15. Koldushko A.A. Nomenklatura $v$ istorii sovetskogo obshchestva [Nomenclature in the History of Soviet Society]. Available at: http://elis.pstu.ru/ index.php?a=9\&pod_id=31\&pod3_id=113\#_edn4. (accessed March 2, 2016).

16. Kommunisticheskaya partiya Sovetskogo Soyuza (KPSS) v rezolyutsiyakh, resheniyakh syezdov, konferentsiy i plenumov TsK [The Communist Party of the Soviet Union (CPSU) in Resolutions, Decisions of Congresses, Conferences and Plenary Sessions of the Central Committee]. Moscow, Politizdat Publ., 1985, vol. 7.576 p.

17. Lubyanka. Stalin $i$ VChK-GPU-OGPUNKVD. Arkhiv Stalina. Dokumenty vysshikh organov partiynoy i gosudarstvennoy vlasti. Yanvar $1922-$ dekabr 1936 [Lubyanka. Stalin and the Soviet State Security Bodies. Stalin's Archive. Documents of the Supreme Bodies of Party and Government Authority. January 1922 - December 1936]. Moscow, Materik Publ., 2003.912p.

18. Mikhalishchev R.A. Yaroslavskaya partiynaya nomenklatura: struktura i dinamika (1936-1939): materialy Vseros. nauch. konf., posvyashchennoy 200-letiyu Yaroslavskogo gosudarstvennogo universiteta im. P.G. Demidova [Yaroslavl Party Nomenclature: Structure and Dynamics (1936-1939): Proceedings of the All-Russian Scientific Conference Devoted to the $200^{\text {th }}$ Anniversary of Yaroslavl State University anmed after P.G. Demidov]. Yaroslavl, 2003, pp. 173-176.

19. Nikonorova T.N. Komissiya partiynogo kontrolya pri TsK VKP(b) (1934-1952 gg.) [Party Control Commission under the Central Committee of the CPSU (b) (1934-1952)]. Rossiiskaya istoriya, 2015, no. 6, pp. 26-40.

20. Okolotin V.S. Ivanovskaya promyshlennaya oblast v 1929-1936 gg. Uroki ekonomicheskoy istorii [Ivanovo Industrial Region in 1929-1936. The Lessons of Economic History]. Ivanovo, IGTA Publ., $2009.528 \mathrm{p}$.

21. Otchet v TsK VKP(b) o rabote Ivanovskogo obkoma partii za 1936 g. Yanvar - dekabr 1936 g. [Report in the Central Committee of the CPSU (b) about the Ivanovo Regional Party Committee's Work in 1936. January - December 1936]. Gosudarstvennyy arkhiv Ivanovskoy oblasti [State Archive of the Ivanovo Region], F. P-327, Op. 5, D. 1078.

22. Pavlova I.V. Mekhanizm vlasti i stroitelstvo stalinskogo sotsializma [The Mechanism of Power and the Construction of Stalin's Socialism]. Novosibirsk, Izd-vo SO RAN, 2001. $460 \mathrm{p}$.

23. Partiynoe stroitelstvo, 1935, no. 13.

24. Perepiska partkollegii s partiynymi i komsomolskimi organizatsiyami. 3 maya - 29 dekabrya 1935 g. [Correspondence of Party Union with Party and Komsomol Organizations. May 3 - December 29, 
1935]. Gosudarstvennyy arkhiv Ivanovskoy oblasti [State Archive of the Ivanovo Region], F. P-367, Op. 1, D. 103.

25. Perepiska s TsK VKP(b) i Komissiey partiynogo kontrolya pri TsK VKP(b) po voprosam organizatsionno-partiynoy raboty i o kadrakh. 1 yanvarya - 20 dekabrya 1935 g. [Correspondence with the Central Committee of the CPSU (b) and the Party Control Commission under the Central Committee of the CPSU (b) on the Party Organizational Work and Personnel. January 1 - December 20, 1935]. Gosudarstvennyy arkhiv Ivanovskoy oblasti [State Archive of the Ivanovo Region], F. P-327, Op. 5, D. 518.

26. Petrov N., Yansen M. «Stalinskiy pitomets»Nikolay Ezhov ["Stalin's Pet" - Nikolay Ezhov]. Moscow, ROSSPEN Publ., 2008. 447 p.

27. Polozheniya o Komissii partiynogo kontrolya pri TsK VKP(b). 1934 g. [The Provisions of the Party Control Commission under the Central Committee of the CPSU (b). 1934]. Rossiyskiy gosudarstvennyy arkhiv sotsialno-politicheskoy istorii [Russian State Archive of Socio-Political History], F. 17, Op. 3, D. 940.

28. Pravda, 1935, 27 March.

29. Pravda, 1935, 7 April.

30. Pravda, 1935, 27 July.

31. Pravda, 1935, 26 August.

32. Pravda, 1936, 25 June.

33. Protokoly partkollegii Komissii partiynogo kontrolya pri TsK VKP(b) po Ivanovskoy oblasti. 28 avgusta - 29 dekabrya $1934 \mathrm{~g}$. [Protocols of Party Union of Party Control Commission under the Central Committee of the CPSU (b) in the Ivanovo Region. August 28 - December 29, 1934]. Gosudarstvennyy arkhiv Ivanovskoy oblasti [State Archive of the Ivanovo Region], F. P-367, Op. 1, D. 2.

34. Rabochiy kray, 1936, 8 January.

35. Rogovin V.Z. Stalinskiy neonep [Stalin's Neonep]. Moscow, Moskva Publ., 1995. 382 p.
36. Spravki, dokladnye zapiski Ivanovskogo obkoma VKP(b) o prorabotke zakrytogo pisma TsK VKP(b) «Uroki sobytiy, svyazannykh so zlodeyskim ubiystvom tov. Kirova», o perestroyke partorganov, realizatsii resheniy noyabrskogo plenuma TsK VKP(b) 1934 g., ob otmene kartochnoy sistemy. 8 fevralya 1934 - 10 fevralya 1935 gg. [Inquiries and Memoranda of Ivanovo Regional Committee of the CPSU (b) on the Elaboration of a Private Letter of the Central Committee of the CPSU (b) "Lessons of the Events Associated with the Villainous Murder of Comrade Kirov", on Restructuring Party Bodies, Implementing the Decisions of the November Plenum of the Central Committee of the CPSU (b) in 1934, on the Abolition of Card System. February 8, 1934 - February 10, 1935]. Gosudarstvennyy arkhiv Ivanovskoy oblasti [State Archive of the Ivanovo Region], F. P-327, Op. 5, D. 355.

37. Spravki NKVD SSSR ob areste vragov naroda i kopii protokolov doprosov. Avgust - oktyabr $1935 \mathrm{~g}$. [Inquiries of NKVD USSR about Arrest of People's Enemies, and Copies of Interrogation Protocols. August - October 1935]. Gosudarstvennyy arkhiv Ivanovskoy oblasti [State Archive of the Ivanovo Region], F. P-367, Op. 1, D. 68.

38. Khlevnyuk O.V. Khozyain. Stalin $i$ utverzhdenie stalinskoy diktatury [Host. Stalin and Approval of Stalin's Dictatorship]. Moscow, ROSSPEN Publ., 2010. 479 p.

39. Shtuder B., Uinfrid B. Stalinskie partiynye kadry. Praktika identifikatsii $i$ diskursa v Sovetskom Soyuze 1930-kh gg. [Stalin's Party Personnel. The Practice of Identification and Discourse in the Soviet Union of the 1930s]. Moscow, ROSSPEN Publ., 2011. 247 p.

40. Yudin K.A. Repressivnaya politika $\mathrm{V}$ otnoshenii nauchno-pedagogicheskoy intelligentsii v 1930-e gg.: metody i praktika [The Repressive Policy towards Scientific and Pedagogical Intelligentsia in the 1930s: Methods and Practice]. Intelligentsiya $i$ mir, 2014, no. 4, pp. 56-73.

\section{Information about the Author}

Kirill A.Yudin, Candidate of Sciences (History), Associate Professor, Department of History of Russia, Ivanovo State University, Timiryazeva St., 5, 153025 Ivanovo, Russian Federation, kirillyudin.hist@mail.ru, http://orcid.org/0000-0001-9579-7056.

\section{Информация об авторе}

Кирилл Александрович Юдин, кандидат исторических наук, доцент кафедры истории России, Ивановский государственный университет, ул. Тимирязева, 5, 153025 г. Иваново, Российская Федерация, kirill-yudin.hist@mail.ru, http://orcid.org/0000-0001-9579-7056. 